\title{
KARAKTERISTIK FISIKOKIMIA MP-ASI BUBUR BAYI INSTAN BERBASIS MOCAF DENGAN SUBSTITUSI TEPUNG TEMPE DAN SUSU SKIM SEBAGAI SUMBER PROTEIN
}

\section{THE PHYSICOCHEMICAL PROPERTIES OF MOCAF-BASED BABY INSTANT PORRIDGE BY TEMPEH FLOUR SUBTITUTION TOWARD SKIM MILK AS A PROTEIN SOURCE}

\author{
Dita Kristanti ${ }^{1)}$, Ainia Herminiati ${ }^{1}$, Neni Yuliantika ${ }^{2)}$ \\ ${ }^{1}$ Pusat Penelitian Teknologi Tepat Guna, Jl. KS Tubun No. 5 Subang, \\ Jawa Barat, 41213, Indonesia \\ 2Jurusan Teknologi Pangan, Universitas Pasundan, Jl. Dr. Setiabudhi No. 193, \\ Bandung. 40153, Indonesia. \\ Email kontributor: dita.kristanti@gmail.com
}

Diterima : 20-08-2020

Direvisi : 15-12-2020

Disetujui : 25-03-2021

\begin{abstract}
ABSTRAK
Bubur bayi instan merupakan jenis Makanan Pendamping Air Susu Ibu (MP-ASI) yang dinilai praktis bagi kalangan ibu yang mempunyai balita. Pembuatan bubur bayi instan dapat dilakukan dengan mensubstitusikan bahan-bahan pangan yang dinilai memiliki kandungan gizi yang baik untuk pertumbuhan bayi. Keterbatasan pemenuhan kebutuhan susu di Indonesia mendorong dilakukannya substitusi tepung tempe terhadap susu skim sebagai sumber protein dalam pembuatan produk ini. Tepung tempe digunakan sebagai bahan alternatif sumber protein karena memiliki kandungan protein yang tinggi dan dinilai lebih ekonomis. Pembuatan MP-ASI bubur bayi instan dilakukan melalui proses pengeringan mengunakan drum dryer. Karakteristik MP-ASI bubur bayi instan adalah sebagai berikut kandungan protein 8,65-9,54\%, lemak 11,19-14,29\%, kalsium 79,76-153,67 mg/100 g, besi 1,97-3,37 $\mathrm{mg} / 100 \mathrm{~g}$, seng $1,40-1,74 \mathrm{mg} / 100 \mathrm{~g}$, daya rehidrasi 4,60-5,58 ml/g, dan densitas kamba 0,38-0,39 $\mathrm{g} / \mathrm{ml}$. Substitusi tepung tempe terhadap susu skim sebagai sumber protein berpengaruh nyata terhadap kandungan protein, lemak, mineral, dan daya rehidrasi produk.
\end{abstract}

Katakunci: bubur bayi instan, MP-ASI, susu skim, tepung tempe

\section{ABSTRACT}

The instant baby porridge is a popular complementary food. It can be made by substituting food ingredients that have proper nutrition for a baby's growth. The substitution of tempeh flour toward skim milk was carried in this product due to the limited stock of milk in Indonesia. Tempeh flour is used as an alternative source of protein. It has a high protein content and more economical than milk. The instant baby porridge is processed by drying it using a drum dryer. The instant baby porridge contains $8.65-9.54 \%$ of protein, $11.19-14.29 \%$ of fat, $79.76-153.67 \mathrm{mg} / 100 \mathrm{~g}$ of calcium, $1.97-3.37$ $\mathrm{mg} / 100 \mathrm{~g}$ of iron, $1.40-1.74 \mathrm{mg} / 100 \mathrm{~g}$ of zinc, $4.60-5.58 \mathrm{ml} / \mathrm{g}$ of rehydration power, and $0.38-0.39 \mathrm{~g} / \mathrm{m}$ of bulk density. The substitution of tempeh flour toward skim milk significantly affects protein, fat, and mineral contents, and the rehydration power of products.

Keywords: complementary food, instant baby porridge, skim milk, tempeh flour

\section{PENDAHULUAN}

akanan Pendamping Air Susu Ibu (MP-ASI) merupakan makanan peralihan dari ASI ke makanan keluarga yang diberikan secara bertahap sesuai kemampuan bayi dalam menerima makanan. Tekstur MP-ASI dari makanan 
lembek menjadi padat ditingkatkan sesuai dengan peningkatan usia bayi. Makanan Pendamping ASI perlu diberikan pada bayi usia 6-24 bulan karena kebutuhan energi setelah usia 6 bulan meningkat sebesar 24-30\% (World Health Organization, 2001). Air susu ibu hanya memenuhi kebutuhan gizi pada usia 6-12 bulan sebesar $60 \%$ sehingga kebutuhan energi tersebut dapat dicukupi dengan pemberian MP-ASI (Mufida et al., 2015). Asupan protein pada bayi usia 6-24 bulan perlu diberikan secara optimal, karena akan berpengaruh terhadap tumbuh kembangnya. Makanan Pendamping Air Susu Ibu yang diberikan pada bayi usia 6-24 bulan harus mengandung karbohidrat dan protein sesuai Angka Kecukupan Gizi (AKG). Angka kecukupan gizi untuk protein terhadap kebutuhan bayi usia 6-11 bulan sebanyak 16 gram (Hardiansyah and Tambunan, 2004), sedangkan kandungan nilai gizi protein yang harus terdapat pada bubur bayi MP-ASI sebesar 8-22\% (Badan Standardisasi Nasional, 2005).

Bubur bayi instan merupakan satu jenis MP-ASI yang populer di kalangan ibu-ibu karena dinilai praktis dalam penyajiannya. Pembuatan bubur bayi instan dalam perkembangannya dilakukan dengan mensubtitusikan bahan-bahan pangan yang dinilai memiliki kandungan gizi yang baik untuk pertumbuhan bayi, seperti mocaf, beras merah, tepung koro putih (Wijatniko, 2013), tepung tempe, labu kuning (Tampubolon et al., 2014), ubi nagara, kalakai, dan pisang (Sholihah et al., 2018). Substitusi bahan pangan tersebut tetap harus mempertimbangkan kebutuhan gizi bayi yang harus seimbang antara karbohidrat, protein, lemak, vitamin, dan mineral.

Modified cassava flour (mocaf) digunakan sebagai sumber karbohidrat dan bahan utama dalam pembuatan bubur instan. Kandungan karbohidrat by difference mocaf cukup tinggi yaitu sebesar 86,28\% (Rosmeri dan Monica, 2013). Pemanfaatan mocaf dilakukan untuk mengurangi ketergantungan terhadap salah satu bahan pangan pokok di Indonesia. Mocaf adalah modifikasi tepung ubi kayu dengan cara fermentasi dengan menggunakan Bakteri Asam Laktat (BAL). Mocaf memiliki karakteristik yang lebih baik dibanding tepung ubi kayu tanpa proses fermentasi, diantaranya adalah peningkatan viskositas, kemampuan gelasi, daya rehidrasi, dan sifat kelarutan (Subagio et al., 2008). Mocaf sudah digunakan sebagai bahan pembuatan bubur bayi (Wijatniko, 2013), biskuit MP-ASI (Agustia et al., 2017), dan puding MP-ASI (Kristanti and Herminiati, 2019a).

Susu merupakan salah satu sumber protein dan kalsium yang sangat penting untuk pembentukan tulang dan pertumbuhan tinggi badan, terutama pada fase pertumbuhan anak. Saat ini, pemenuhan kebutuhan susu Indonesia masih sangat bergatung pada negara lain. Kebutuhan susu di Indonesia pada tahun 2016 dipenuhi dari 19,12\% susu sapi lokal dan $80,80 \%$ susu impor (Agustina, 2016). Kondisi ini mendorong penggunaan bahan pangan non-susu sebagai alternatif sumber protein.

Tempe merupakan produk makanan yang terbuat dari kacang kedelai melalui proses fermentasi oleh jamur Rhizopus $s p$. Tempe dikenal sebagai sumber protein nabati yang digemari oleh masyarakat Indonesia karena harganya relatif murah. Kandungan protein pada tempe kedelai cukup tinggi. Menurut Rahayu et al. (2015), kandungan protein tempe segar sebesar $18,3 \%$ sedangkan tepung tempe sebesar $48,75 \%$. Namun, protein nabati atau protein yang berasal dari tumbuhan biasanya tidak mengandung asam amino esensial yang lengkap. Kacang-kacangan seperti kedelai biasanya kekurangan asam amino metionin dan sistein (Romero-velarde et al., 2017). Pada pembuatan MP-ASI bubur instan dilakukan dengan mensubstitusi tepung tempe dengan susu skim untuk memenuhi kebutuhan protein, terutama asam amino sistein dan metionin. Kandungan asam amino sistein dan metionin susu skim berkisar antara 7,13-8,14 dan 33,3-34,6 g/100g protein (Magan et al., 2019). Penelitian ini bertujuan untuk mengetahui pengaruh penggunaan tepung tempe pada konsentrasi berbeda terhadap kandungan gizi, terutama protein dan mineral pada produk MP-ASI bubur bayi instan. 


\section{METODEPENELITIAN}

Bahan yang digunakan dalam penelitian ini adalah mocaf dari UKM Tanjung Siang Subang, tempe dari Kopti Subang, susu skim dari Toko Ny. Liem Bandung, Orafti ${ }^{\circledR}$ inulin (Synergy1-Oligofructose, 112), gula halus, dan minyak kelapa sawit dari toko lokal di Subang. Peralatan yang digunakan dalam penelitian ini adalah timbangan digital, cabinet dryer, steam jacket kettle, drum dryer, blender, disc mil, vibrator screen mesh 40, dan sealer.

Tempe dibuat dari kacang kedelai impor yang diperoleh dari UKM binaan Kopti Subang. Proses pembuatan tepung tempe adalah sebagai berikut: tempe segar diiris dengan ketebalan $\pm 10-20 \mathrm{~mm}$, potongan tempe dikukus pada suhu $75-85^{\circ} \mathrm{C}$ selama 10 menit untuk menonaktifkan enzim dan jamur pada tempe, selanjutnya potongan tempe ditiriskan dan dikeringkan menggunakan cabinet dryer pada suhu $50^{\circ} \mathrm{C}$ selama \pm 5 jam. Potongan tempe yang telah kering kemudian ditepungkan dan diayak menggunakan ayakan 40 mesh (Kristanti et al., 2020).

\section{Pembuatan Bubur Bayi Instan}

Rancangan penelitian menggunakan Rancangan Acak Lengkap (RAK) dengan faktor perbandingan konsentrasi tepung tempe dan susu skim. Pada penelitian ini terdapat 3 perlakuan, yaitu $\mathrm{F} 1$ = tepung tempe $75 \%$ dan susu skim $25 \%$, F2 = tepung tempe $50 \%$ dan susu skim $50 \%$, dan F3= tepung tempe $25 \%$ dan susu skim $75 \%$ dimana setiap perlakuan menggunakan 3 ulangan.

Formulasi dan tahapan pembuatan bubur bayi instan mengacu pada (Herminiati et al., 2020). Pembuatan bubur bayi instan dilakukan menggunakan tepung tempe dan susu skim sebagai sumber protein. Formula bubur bayi instan ditampilkan pada Tabel 1.

Tabel 1. Formula bubur bayi instan $(\mathrm{g})$

\begin{tabular}{lccc}
\hline \multicolumn{1}{c}{ Bahan } & F1 & F2 & F3 \\
\hline Mocaf & 450 & 450 & 450 \\
Tepung tempe & 143,95 & 95.975 & 48 \\
Susu skim & 48 & 95.975 & 143,95 \\
Inulin & 8 & 8 & 8 \\
Gula halus & 250 & 250 & 250 \\
Minyak kelapa sawit & 100 & 100 & 100 \\
Bubuk vanili & 0,05 & 0,05 & 0,05 \\
\hline
\end{tabular}

Keterangan: $F 1=$ tepung tempe $75 \%$ dan susu skim 25\%, F2 = tepung tempe $50 \%$ dan susu skim 50\%, F3= tepung tempe 25\% dan susu skim 75\% (Herminiati et al., 2020)

\section{Komposisi Kimia dan Sifat Fisik}

Komposisi kimia yang dianalisis antara lain adalah kadar air, abu, protein, lemak, karbohidrat, dan mineral. Analisis kadar air dan abu dilakukan menggunakan metode gravimetri (Association of Official Analytical Chemist, 1995), protein menggunakan metode Dumas dengan alat DuMAster Buchi D-480, Switzerland, lemak menggunakan metode Soxhlet, dan kadar karbohidrat ditentukan menggunakan metode by difference (Association of Official Analytical Chemist, 1995). Kadar mineral kalsium (Ca), besi (Fe), dan seng (Zn) dianalisis menggunakan flame atomic absorption spectrometry (AAS) GBC Type 933AA.

Pengukuran densitas kamba dilakukan dengan menimbang sampel yang telah dimasukkan ke dalam gelas ukur $100 \mathrm{ml}$ sampai volume $100 \mathrm{ml}$. Pengisian harus tepat pada 
tanda tera dan tidak boleh dipadatkan. Densitas kamba dinyatakan dalam bobot/100 ( $\mathrm{g} / \mathrm{ml})$ (Handayani et al., 2014).

Pengukuran daya rehidrasi dilakukan dengan menambahkan $10 \mathrm{ml}$ air ke dalam tabung sentrifuse yang berisi 1 gram sampel, kemudian diaduk dan didiiamkan selama 30 menit pada suhu kamar. Selanjutnya campuran disentrifus dengan kecepatan 3500 rpm selama 30 menit. Daya rehidrasi dihitung dengan persamaan 1 (Handayani et al., 2014).

$$
\text { dayarehidrasi }\left(\frac{m l}{g}\right)=\frac{A-B}{C} \ldots \ldots
$$

Keterangan: $A=$ volume air mula-mula $(\mathrm{ml}), \quad B=$ volume supernatan $(\mathrm{ml})$, dan $\mathrm{C}=$ bobot sampel $(g)$.

\section{Analisis Statistik}

Data dianalisis menggunakan program IBM SPSS Statistics 20. Data dianalisis menggunakan analisis varian (ANOVA) yang kemudian dilanjutkan uji Duncan dengan tingkat signifikansi $p<0,05$. Semua data ditampilkan sebagai rata-rata dengan standar deviasi.

\section{HASIL DAN PEMBAHASAN \\ Komposisi Kimia Mocaf, Tepung Tempe, dan Susu Skim}

Komposisi kimia mocaf, tepung tempe dan susu skim yang digunakan dalam pembuatan MP-ASI bubur bayi instan ditampilkan pada Tabel 2. Mocaf digunakan dalam pembuatan produk ini sebagai sumber karbohidrat, sedangkan tepung tempe dan susu skim disubstitusikan sebagai sumber protein. Pemanfaatan mocaf ini sebagai salah satu upaya diversifikasi sumber karbohidrat.

Komposisi kimia mocaf pada penelitian ini tidak jauh berbeda dari penelitian Rosmeri dan Monica (2013). Mocaf mengandung 11,00\% air, 1,44\% abu, 0,98\% protein, dan 0,30\% lemak (Rosmeri and Monica, 2013). Berdasarkan persyaratan Codex Standard 176-1989, mocaf harus mengandung air maksimal $13 \%$, abu maksimal 0,2\%, protein maksimal $1 \%$, lemak 0,4-0,8\%, pati 85-87\%, serat 1,9-3,4\%, dan negatif HCN (Subagio et al., 2008). Mocaf yang digunakan untuk pembuatan bubur bayi instan ini sudah sesuai dengan persyaratan Codex Standard 176-1989, hanya untuk kadar lemak masih lebih tinggi. Hasil penelitian Ratnawati et al. (2016) menunjukkan bahwa mocaf mengandung 6,78\%bb air, 0,76\%bb abu, 2,70\%bb protein, 0,90\%bb lemak, 88,95\%bb karbohidrat dan 0,01 ppm HCN.

Tabel 2. Komposisi Kimia Mocaf, Tepung Tempe, dan Susu Skim yang digunakan dalalm Pembuatan MP-ASI Bubur Bayi Instan

\begin{tabular}{lccccc}
\multirow{2}{*}{ Bahan } & \multicolumn{5}{c}{ Komposisi kimia (\%bk) } \\
\cline { 2 - 6 } & Air & Abu & Protein & Lemak & $\begin{array}{c}\text { Karbo } \\
\text { hidrat }\end{array}$ \\
\hline Mocaf & $11,54 \pm 0,09$ & $1,12 \pm 0,00$ & $0,55 \pm 0,04$ & $4,81 \pm 0,14$ & $81,96 \pm 0,21$ \\
Tepung tempe & $10,78 \pm 0,14$ & $1,10 \pm 0,23$ & $45,25 \pm 0,10$ & $35,18 \pm 0,35$ & $7,63 \pm 0,46$ \\
Susu skim & $3,97 \pm 0,06$ & $0,97 \pm 0,00$ & $38,21 \pm 0,06$ & $4,15 \pm 0,23$ & $52,73 \pm 0,14$ \\
\hline
\end{tabular}

Nilai yang ditampilkan merupakan rata-rata \pm standar deviasi.

Tepung tempe memiliki kandungan air sebesar 2,25-7,70\%, abu sebesar 1,93-2,30\%, protein sebesar 46,00- 50,18\%, lemak 24,70-25,02\%, dan karbohidrat sebesar 19,3022,88\% (Astawan et al., 2016; Bastian et al., 2013). Kandungan air dan lemak tepung tempe pada penelitian ini lebih tinggi dari hasil penelitian Astawan et al. (2016) dan Bastian et al. (2013), sedangkan kandungan abu, protein, dan karbohidrat lebih rendah. Tepung tempe 
pada penelitian ini dikeringkan menggunakan cabinet dryer pada suhu $50^{\circ} \mathrm{C}$ selama 5 jam dengan kadar air sebesar $10,78 \%$, sedangkan pada penelitian sebelumnya tepung tempe dikeringkan dengan menggunakan metode freeze drying dengan kadar air sebesar 2,25\%, (Astawan dkk., 2016) dan oven blower pada suhu $70^{\circ} \mathrm{C}$ selama 7 jam dengan kadar air sebesar 7,70\% (Bastian dkk., 2013). Perbedaan metode, suhu, dan lama pengeringan menyebabkan perbedaan kandungan air tepung tempe pada penelitian ini dengan penelitian sebelumnya. Kadar air tepung tempe sebesar $10,78 \%$ pada penelitian ini memenuhi syarat standar tepung. Kadar air tepung terigu maksimal sebesar 14,5\% (Badan Standardisasi Nasional, 2009). Kadar air tepung jagung maksimal sebesar 14\% (Badan Standardisasi Nasional, 2020).

Kandungan lemak susu skim yang rendah dan karbohidrat yang tinggi berkaitan dengan proses pembuatannya. Pembuatan susu skim dilakukan dengan memisahkan skim dari krim susu yang mengandung lemak. Proses pemisahan ini menyebabkan kandungan lemak susu skim relatif rendah dan ada potensi hilangnya vitamin larut lemak dari susu. Di Indonesia, susu skim umumnya diproduksi dalam bentuk bubuk melalui proses pengeringan kering (spray drying). Proses spray drying seringkali dilakukan dengan menambahkan maltodekstrin sebagai bahan pengisi.

\section{Komposisi Kimia MP-ASI Bubur Bayi Instan}

Pembuatan MP-ASI bubur bayi instan dilakukan dengan pengeringan menggunakan drum dryer. Menurut Tang et al. (2003), pengeringan menggunakan drum dryer merupakan metode terbaik untuk bahan pangan yang berbentuk puree, pasta, dan pati tergelatinisasi. Kandungan kimia MP-ASI bubur bayi instan ditampilkan pada Tabel 3. Syarat mutu MP-ASI bubuk berdasarkan SNI 01-7111.1-2005 adalah kandungan air maksimal 4\%, abu maksimal 3,5\%, protein 8-22\%, dan lemak 6-15\% (Badan Standardisasi Nasional, 2005). Secara umum, MP-ASI bubur bayi instan F2 dan F3 memenuhi syarat mutu SNI. Kandungan air F1 melebihi standar mutu SNI dan lebih tinggi $(p<0,05)$ dibanding F2 dan F3. Kandungan air F1 yang tinggi disebabkan oleh penambahan tepung tempe yang paling besar pada formula ini yaitu $75 \%$. Kandungan air tepung tempe lebih tinggi dibanding susu skim (Tabel 2). Pengeringan dengan suhu dan waktu yang sama pada bubur MP-ASI instan menyebabkan air yang tertinggal pada F1 jauh lebih banyak dibanding F2 dan F3.

Tabel 3. Komposisi Kimia MP-ASI Bubur Bayi Instan

\begin{tabular}{lccccc} 
MP-ASI bubur & \multicolumn{5}{c}{ Komposisi kimia (\%bk) } \\
\cline { 2 - 6 } bayi instan & Air & Abu & Protein & Lemak & Karbohidrat \\
\hline F1 & $4,99 \pm 0,11^{\mathrm{a}}$ & $1,04 \pm 0,00^{\mathrm{a}}$ & $9,54 \pm 1,95^{\mathrm{a}}$ & $14,29 \pm 0,45^{\mathrm{a}}$ & $70,14 \pm 0,46^{\mathrm{c}}$ \\
F2 & $4,02 \pm 0,26^{\mathrm{b}}$ & $1,03 \pm 0,01^{\mathrm{b}}$ & $8,72 \pm 0,37^{\mathrm{b}}$ & $13,51 \pm 0,72^{\mathrm{a}}$ & $72,72 \pm 0,97^{\mathrm{b}}$ \\
F3 & $3,84 \pm 0,12^{\mathrm{b}}$ & $1,02 \pm 0,00^{\mathrm{c}}$ & $8,65 \pm 0,03^{\mathrm{b}}$ & $11,19 \pm 0,57^{\mathrm{b}}$ & $76,29 \pm 0,54^{\mathrm{a}}$ \\
\hline
\end{tabular}

Nilai yang ditampilkan merupakan rata-rata \pm standar deviasi. Nilai rata-rata pada kolom yang sama dengan huruf berbeda menunjukkan perbedaan signifikan $p<0,05$. Keterangan: $F 1=$ tepung tempe 75\% dan susu skim 25\%, F2 = tepung tempe 50\% dan susu skim 50\%, F3 = tepung tempe $25 \%$ dan susu skim $75 \%$

Hasil penelitian menunjukkan bahwa kandungan protein $F 1$ lebih tinggi $(p<0,05)$ dibanding F2 dan F3, sedangkan kandungan protein F2 dan F3 tidak berbeda nyata. Kandungan protein F2 dan F3 yang tidak berbeda nyata menandakan bahwa penambahan tepung tempe sebesar $50 \%$ dan $25 \%$ pada formula tidak memberikan efek pada kandungan protein bubur MP-ASI instan. Kandungan lemak F1 dan F2 tidak berbeda nyata dan lebih 
tinggi ( $p<0,05$ ) dibanding F3. Kandungan lemak pada F1 dan F2 yang tidak berbeda nyata menandakan bahwa penambahan susu skim sebesar $25 \%$ dan $50 \%$ pada formula tidak memberikan efek pada kandungan lemak bubur MP-ASI instan. Kandungan protein dan lemak MP-ASI bubur bayi instan menurun sejalan dengan penurunan komposisi tepung tempe pada formulasi. Kandungan protein dan lemak yang tinggi pada F1 berasal dari tepung tempe. Dari hasil analisa (Tabel 2), kandungan protein dan lemak tepung tempe lebih tinggi dibandingkan susu skim. Hasil penelitian Kristanti et al. (2020) menunjukkan bahwa penambahan tepung tempe menyebabkan peningkatan kandungan protein dan lemak pada pembuatan kukis mocaf.

\section{Kandungan Mineral MP-ASI Bubur Bayi Instan}

Kandungan mineral MP-ASI bubur bayi instan ditampilkan pada Tabel 4. Kandungan kalsium dan seng MP-ASI bubur bayi instan mengalami peningkatan sejalan dengan peningkatan komposisi susu skim pada formulasi. Kandungan kalsium F3 lebih tinggi ( $p<$ 0,05 ) dibanding F1 dan F2. Sama halnya dengan kandungan protein dan lemak, kandungan kalsium yang tinggi pada F2 dan F3 berasal dari susu skim. Kandungan kalsium pada susu skim sebesar $1280 \mathrm{mg} / 100 \mathrm{~g}$ (Zamberlin et al., 2012) lebih tinggi dibanding tepung tempe sebesar 292,88 mg/100 g (Astawan et al., 2016).

Tabel 4. Kandungan Mineral MP-ASI Bubur Bayi Instan

\begin{tabular}{lccc}
\hline MP-ASI bubur & \multicolumn{3}{c}{ Kandungan mineral (mg/100 g) } \\
\cline { 2 - 4 } bayi instan & Kalsium (Ca) & Besi (Fe) & Seng (Zn) \\
\hline F1 & $79,76 \pm 0.00^{\mathrm{c}}$ & $3,37 \pm 0,01^{\mathrm{a}}$ & $1,50 \pm 0,02^{\mathrm{b}}$ \\
F2 & $116,65 \pm 4,03^{\mathrm{b}}$ & $2,04 \pm 0,02^{\mathrm{b}}$ & $1,40 \pm 0,78^{\mathrm{b}}$ \\
F3 & $153,67 \pm 0.00^{\mathrm{a}}$ & $1,97 \pm 0,02^{\mathrm{c}}$ & $1,74 \pm 0,02^{\mathrm{a}}$ \\
\hline
\end{tabular}

Nilai yang ditampilkan merupakan rata-rata \pm standar deviasi. Nilai rata-rata pada kolom yang sama dengan huruf berbeda menunjukkan perbedaan signifikan $p<0,05$. Keterangan: $F 1=$ tepung tempe $75 \%$ dan susu skim 25\%, F2 = tepung tempe 50\% dan susu skim 50\%, F3 = tepung tempe $25 \%$ dan susu skim $75 \%$.

Kandungan besi MP-ASI bubur bayi instan mengalami penurunan sejalan dengan penurunan komposisi tepung tempe pada formulasi. Kandungan besi F1 lebih tinggi $(p<$ 0,05 ) dibanding F2 dan F3, sedangkan kandungan besi pada F2 dan F3 tidak berbeda nyata. Kandungan besi yang tinggi pada $\mathrm{F} 1$ berasal dari tepung tempe. Kandungan besi tepung tempe sebesar $8,10 \mathrm{mg} / 100 \mathrm{~g}$ (Astawan et al., 2016) lebih tinggi dibanding susu skim sebesar 0,27 mg/100 g (Zamberlin et al., 2012). Hasil penelitian (Kristanti et al., 2020) menunjukkan bahwa kandungan besi pada kukis mocaf meningkat seiring dengan penambahan tepung tempe.

Kandungan seng F3 signifikan lebih tinggi $(p<0,05)$ dibanding F1 dan F2. Hasil ini tidak didukung dengan hasil penelitian sebelumnya, dimana kandungan seng pada susu skim $4 \mathrm{mg} / 100 \mathrm{~g}$ (Zamberlin et al., 2012) lebih rendah dibanding tepung tempe sebesar 5,35 $\mathrm{mg} / 100 \mathrm{~g}$ (Astawan et al., 2016). Kandungan seng F3 yang lebih tinggi dari F1 dan F2 kemungkinan berasal dari susu skim yang merupakan faktor perlakuan pada penelitian ini. Namun, pada penelitian ini tidak dilakukan pengujian mineral pada bahan baku sehingga masih perlu dilakukan pengujian lebih lanjut.

Kebutuhan mineral kalsium, besi dan seng pada bayi usia 7-12 bulan berdasarkan angka kecukupan gizi adalah sebesar $250 \mathrm{mg}, 7 \mathrm{mg}$, dan $3 \mathrm{mg}$. Berdasarkan angka 
kecukupan gizi, produk bubur bayi instan dengan takaran saji $25 \mathrm{~g}$ mampu memenuhi 7,97$15,37 \%$ kebutuhan kalsium, 7,00-12,00\% kebutuhan besi, dan 11,67-12,50\% kebutuhan seng. Kandungan mineral pada MP-ASI bubur bayi instan masih kurang dari syarat mutu yang ditentukan. Syarat mutu MP-ASI bubuk berdasarkan SNI 01-7111.1-2005 adalah kandungan kalsium minimal $200 \mathrm{mg} / 100 \mathrm{~g}$, besi minimal $5 \mathrm{mg} / 100 \mathrm{~g}$, dan seng minimal 2,5 $\mathrm{mg} / 100 \mathrm{~g}$ (Badan Standardisasi Nasional, 2005). Upaya peningkatan kandungan mineral dapat dilakukan dengan fortifikasi mineral mix pada produk. Fortifikasi mikronutrien yang mengandung lebih dari $50 \mathrm{mg} / \mathrm{kg}$ besi, $30 \mathrm{mg} / \mathrm{kg}$ seng, $4 \mathrm{mg} / \mathrm{kg}$ vitamin B2, 2,5 mg/kg vitamin B1, dan $2 \mathrm{mg} / \mathrm{kg}$ asam folat sebesar 0,015\% terbukti menyebabkan peningkatan kandungan besi dan seng tiga kali lipat lebih tinggi dibanding kontrol pada bubuk puding MPASI (Kristanti dan Herminiati, 2019b). Upaya serupa juga dapat dilakukan untuk memenuhi syarat mutu bubur bayi instan sesuai dengan SNI 01-7111.1-2015.

\section{Daya Rehidrasi MP-ASI Bubur Bayi Instan}

Pembuatan MP-ASI bubur bayi instan melalui tahapan gelatinisasi menggunakan steam jacket cattle sebelum proses pengeringan menggunakan drum dryer. Proses gelatinisasi ini akan berpengaruh terhadap kemampuan daya rehidrasi produk. Daya rehidrasi adalah tingkat penyerapan air kembali ke dalam suatu bahan kering menggandung pati yang sebelumnya telah mengalami gelatinisasi. Daya rehidrasi yang tinggi menunjukkan tingkat keberhasilan pembuatan produk instan.

Daya rehidrasi MP-ASI bubur instan mengalami peningkatan sejalan dengan peningkatan komposisi susu skim pada formulasi, ditampilkan pada Gambar 1. Daya rehidrasi F2 dan F3 tidak berbeda nyata dan lebih tinggi $(p<0,05)$ dibanding F1. Daya rehidrasi sangat dipengaruhi oleh kandungan pati bahan. Semakin banyak kandungan pati pada bahan akan meningkatkan proses gelatinisasi dan penyerapan air. Selain kandungan pati, kandungan protein juga sangat berpengaruh terhadap daya rehidrasi air pada suatu bahan. Daya rehidrasi air berhubungan dengan jumlah gugus amino polar yang terdapat dalam molekul protein, seperti hidroksil, amino, karboksil, dan sulfidril. Gugus amino polar pada protein memiliki sifat hidrofilik sehingga mampu meningkatkan penyerapan air pada suatu bahan. Asam amino yang mengandung gugus sulfidril adalah sistein dan metionin. Kandungan asam amino sistein dan metionin pada susu skim sebesar 7,13-8,14 dan 33,3$34,6 \mathrm{~g} / 100 \mathrm{~g}$ protein (Magan et al., 2019) lebih tinggi dibandingkan tepung tempe sebesar 0,245 dan 0,016 g/100 g protein (Wan Saidatul Syida et al., 2018). Kandungan asam amino sistein dan metionin susu skim yang lebih tinggi daripada tepung tempe kemungkinan menyebabkan daya serap air yang lebih tinggi pada bubur instan F2 dan F3.

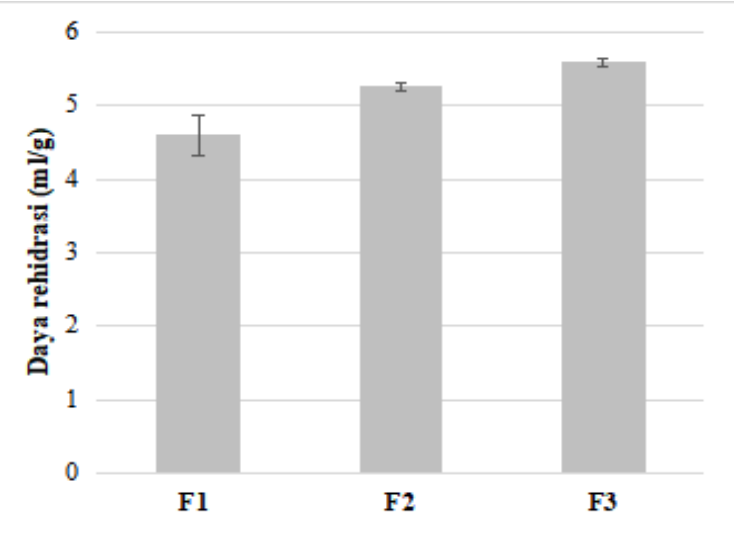

Gambar 1. Daya Rehidrasi MP-ASI Bubur Bayi Instan 
Keterangan: $F 1=$ tepung tempe $75 \%$ dan susu skim 25\%, F2 = tepung tempe 50\% dan susu skim $50 \%, F 3$ = tepung tempe $25 \%$ dan susu skim $75 \%$.

\section{Densitas Kamba MP-ASI Bubur Bayi Instan}

Selain daya rehidrasi, densitas kamba merupakan salah satu parameter keberhasilan pembuatan produk instan untuk bayi. Nilai densitas kamba yang tinggi sangat diharapkan pada produk instan untuk bayi. Produk dengan nilai densitas tinggi memiliki kepadatan nilai gizi yang tinggi sehingga setelah penyeduhan dengan air hangat diharapkan bubur bayi instan ini dapat mencukupi kebutuhan gizi bayi dengan kondisi volume lambung bayi yang relatif kecil. Kapasitas fungsional lambung bayi hanya sekitar $30 \mathrm{~g} / \mathrm{kg}$ berat badan (Sholihah et al., 2018). Nilai densitas kamba MP-ASI bubur bayi instan berkisar antara 0,38-0,39 g/ml, dan tidak berbeda nyata $(p<0,05)$ antara ketiga formulasi. Nilai denistas kamba ditampilkan pada Gambar 2. Nilai densitas kamba MP-ASI hasil optimasi formula menggunakan Response Surface Methodology (RSM) berkisar antara 0,57-0,59 g/ml, sedangkan densitas kamba MPASI bubur bayi komersial berkisar antara 0,37-0,50 g/ml (Hadiningsih, 2004). Nilai densitas kamba F1, F2, dan F3 masih dalam kisaran densitas kamba MP-ASI bubur bayi komersial.

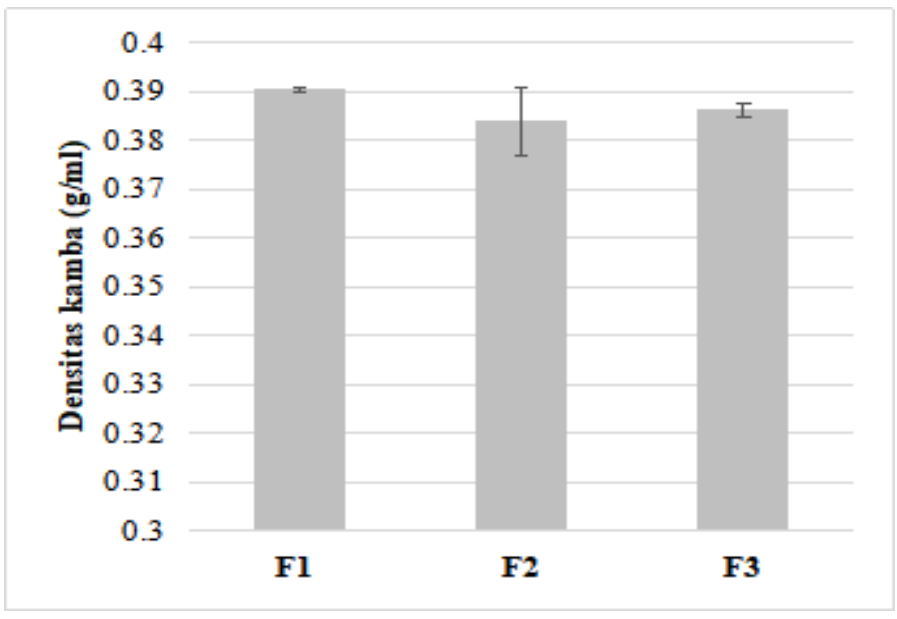

Gambar 2. Densitas Kamba MP-ASI Bubur Bayi Instan

Keterangan: $\mathrm{F} 1$ = tepung tempe $75 \%$ dan susu skim $25 \%$, F2 = tepung tempe $50 \%$ dan susu skim $50 \%$, F3 = tepung tempe $25 \%$ dan susu skim $75 \%$

Berdasarkan karakteristik fisikokimia yang telah dianalisis, bubur bayi instan yang terbaik adalah F3. Kandungan air, abu, protein, dan lemak bubur bayi instan F3 sesuai dengan Standar Nasional Indonesia. Selain itu, bubur bayi instan F3 memiliki daya rehidrasi yang paling tinggi diantara yang lain.

Daya rehidrasi dan densitas kamba merupakan sifat fisik yang penting pada produk bubur bayi instan. Daya rehidrasi berhubungan dengan tingkat penyerapan air kembali dan tingkat kelarutan pada suatu produk. Semakin tinggi daya rehidrasi menunjukkan semakin banyak air yang terserap pada suatu bahan sehingga tingkat kelarutan produk juga semakin tinggi. Tingkat kelauratan produk yang tinggi akan menghasilkan tekstur bubur yang halus. Tektur bubur yang halus sangat diharapkan pada produk bubur bayi instan. Hal ini berkaitan 
dengan pola pemberian MP-ASI bubur bayi pada usia 6-12 bulan yang harus dalam bentuk makanan halus. Densitas kamba berbanding lurus dengan tingkat kepadatan gizi pada suatu produk. Nilai densitas kamba yang tinggi pada suatu produk megindikasikan bahwa kuantitas produk yang rendah memiliki tingkat kepadatan gizi yang tinggi. Produk bubur bayi instan diharapkan memiliki tingkat kepadatan yang tinggi. Hal ini berhubungan dengan kondisi volume lambung bayi yang relatif kecil sehingga diharapkan dengan volume produk yang sedikit dapat memenuhi kebutuhan gizi bayi. Oleh karena itu, sifat daya rehidrasi dan densitas kamba sangat diperlukan pada produk bubur bayi instan.

\section{KESIMPULAN}

Penggunaan tepung tempe pada konsentrasi berbeda berpengaruh nyata terhadap kandungan gizi produk MP-ASI bubur bayi instan. Penambahan tepung tempe dengan konsentrasi yang semakin tinggi menghasilkan kandungan air, abu, protein, lemak, dan besi yang lebih tinggi; serta kandungan kalsium dan seng yang lebih rendah pada produk MPASI bubur bayi instan. Selain itu, penggunaan tepung tempe yang semakin tinggi menghasilkan daya rehidrasi yang lebih rendah, tetapi tidak mempengaruhi densitas kamba pada produk MP-ASI bubur bayi instan.

\section{UCAPAN TERIMA KASIH}

Penulis mengucapkan terima kasih kepada Kementrian Ristek Dikti atas pendanaan penelitian ini melalui program Insensif Riset Sistem Inovasi Nasional (INSINAS) dengan nomor kontrak 065/P/RPL-LIPI/INSINAS/II/2019 untuk dukungan dana penelitian. Ucapan terima kasih juga disampaikan kepada P2 TTG LIPI atas penyediaan fasilitas penelitian.

\section{DAFTAR PUSTAKA}

Agustia, F. C., Y. P. Subardjo, dan H. P. Sari. 2017. Pengembangan Biskuit Mocaf-Garut dengan Substitusi Hati Sebagai Alternatif Biskuit Tinggi Besi untuk Balita. Jurnal Gizi Pangan, 12(2):129-139. doi: 10.25182/jgp.2017.12.2.129-138.

Agustina, T. 2016. Outlook Susu Komoditas Pertanian Subsektoral Peternakan. Diedit oleh L. Nuryati dan A. Yasin. Pusat Data dan Sistem Informasi Pertanian, Sekertariat Jenderal Kementrian Pertanian. Jakarta.

Association of Official Analytical Chemist. 1995. Official Methods of Analysis of The Association of Official Analytical Chemist, 14 ed. AOAC Inc. Airilington.

Astawan, M., T. Wresdiyati, dan M. Ichsan. 2016. Karakteristik Fisikokimia Tepung Tempe Kecambah Kedelai. Jurnal Gizi Pangan, 11(1):35-42.

Badan Standardisasi Nasional (2005) SNI 01-7111.1-2015 Makanan Pendamping Air Susu Ibu (MP-ASI)-Bagian 1: Bubuk Instan. Badan Standardisasi Nasional. Jakarta.

Badan Standardisasi Nasional (2009) SNI 3751:2009 Tepung Terigu sebagai Bahan Makanan, Badan Standardisasi Nasional. Jakarta.

Badan Standardisasi Nasional (2020) Tepung Jagung. Badan Standardisasi Nasional. Jakarta.

Bastian, F., E. Ishak, A. B. Tawali, dan M. Bilang. 2013. Daya Terima dan Kandungan Zat Gizi Formula Tepung Tempe dengan Penambahan Semi Refined Carrageenan (SRC) dan Bubuk Kakao. Jurnal Aplikasi Teknologi Pangan, 2(1):5-8.

Hadiningsih, N. 2004. Optimasi Formula Makanan Pendamping ASI dengan Menggunakan Response Surface Methodology (RSM). Institut Pertanian Bogor.

Handayani, N. A., H. Santosa, B. A. Adietya, B. Profegama, dan A. Yuna. 2014. Karakteristik Fisik Bubur Bayi Instan dari Tepung Ubi Jalar Ungu Terfortifikasi Zink (Zn). Prosiding Seminar Nasional Sains Dan Teknologi ke-5 Tahun 2014. 1(1):65-70.

Hardiansyah dan V. Tambunan. 2004. Angka Kecukupan Energi, Protein, Lemak, dan Serat

20 Dita Kristanti, Ainia Herminiati, Neni Yuliantika

Karakteristik Fisikokimia MP-ASI Bubur Bayi Instan Berbasis Mocaf

dengan Substitusi Tepung Tempe dan Susu Skim sebagai Sumber Protein 
Makanan. Widyakarya Nasional Pangan dan Gizi VIII "Ketahanan Pangan dan Gizi di Era Otonomi Daerah. Jakarta.

Herminiati, A., D. Kristanti, Rimbawan, I. D. Astuti, N. S. Achyadi, dan N. Yuliantika. 2020. Characteristics of Inulin-Enriched Instant Porridge and its Effectiveness to Increase Calcium Absorption in Infant Rat Models. Current Research in Nutrition and Food Science, 08(1):256-267.

Kristanti, D. dan A. Herminiati. 2019a. Characteristics of physical, chemical, and organoleptic properties of inulin-enriched pudding as a complementary food. IOP Conference Series: Earth and Environmental Science. IOP Publishing. doi: 10.1088/1755$1315 / 251 / 1 / 012032$.

Kristanti, D. dan A. Herminiati. 2019b. Physicochemical properties of pudding powder as a complementary food fortified with the essential mineral. AIP Conference Proceedings, 2175(November):020053-6-020053-6. doi: 10.1063/1.5134617.

Kristanti, D., W. Setiaboma. dan A. Herminiati. 2020. Karakteristik Fisikokimia dan Organoleptik Cookies Mocaf dengan Penambahan Tepung Tempe. Biopropal Industri, 11(1):1-8. doi: http://dx.doi.org/10.36974/jbi.v11i1.5354.

Magan, J. B., T. F. O'Callaghan, J. Zheng, L. Zhang, R. Mandal, D. Hennessy, M. A. Fenelon, D. S. Wishart, A. L. Kelly, dan N. A. McCathy .2019. Impact of bovine diet on metabolomic profile of skim milk and whey protein ingredients. Metabolites, 9(305):1-14. doi: 10.3390/metabo9120305.

Mufida, L., T. D. Widyaningsih dan J. M. Maligan. 2015. Prinsip Dasar Makanan Pendamping Air Susu Ibu (MP-ASI) untuk Bayi 6-24 Bulan: Kajian Pustaka. Jurnal Pangan dan Agroindustri. 3(4):1646-1651.

Rahayu, W. P., R. Pambayun, U. Santoso, L. Nuraida, dan Ardiansyah. 2015. Tinjauan IImiah Teknologi Pengolahan Tempe Kedelai. Edisi 1. Perhimpunan Ahli Teknologi Pangan (PATPI). Tersedia pada: http:/patpi.or.id.

Ratnawati, L., N. K. I. Mayasti, A. Sarifudin, S. K. D. F. A. Putri, S. Hartati, dan Hartati. 2016. Starter Mocaf dan Pembuatannya. P00201604227.

Romero-velarde, Enrique, S. Villalpando-carrión, A. B. Pérez-lizaur, Ma. de la L. Irachetagerez, C. G. Alonso-rivera, G. E. López-navarrete, A. García-contreras, et al. 2017. Guidelines for Complementary Feeding in Healthy Infants. Boletín Médico del Hospital Infantil de México (English Edition). Hospital Infantil de México Federico Gómez, 73(5):338-356. doi: 10.1016/j.bmhime.2017.11.007.

Rosmeri, V. I. dan B. N. Monica. 2013. Pemanfaatan Tepung Umbi Gadung (Dioscorea hispida Dennst) dan Tepung MOCAF (Modified Cassava Flour) Sebagai Bahan Substitusi dalam Pembuatan Mie Basah, Mie Kering, dan Mie Instan," Teknologi Kimia Dan Industri, 2(2):246-256.

Sholihah, N. M., L. Agustina, dan A. Nugroho. 2018. Formulasi Tepung Bubur Bayi Berbahan Dasar Ubi Nagara dan Kalakai (Stenochlaena palustris) sebagai Bahan Fortifikasi Zat Besi dengan Flavor Alami Pisang Ambon. Jurnal Riset Industri Hasil hutan, 10(2):75-82.

Subagio, A., W. Siti W, Y. Witono, dan F. Fahmi. 2008. Prosedur Operasi Standar (POS) Produksi Mocal Berbasis Klaster. Bogor: Southeast Asian Food and Agricultural Science and Technology (SEAFAST) Center, Institut Pertanian Bogor.

Tampubolon, N. L., T. Karo-karo, dan Ridmwansyah. 2014. Formulasi Bubur Bayi Instan dengan Substitusi Tepung Tempe dan Tepung Labu Kuning sebagai Alternatif Makanan Pedamping ASI. Jurnal Rekayasa Pangan dan Pertanian, 2(2):78-83.

Tang, J., H. Feng, dan G. Shen. 2003. Drum drying," Encyclopedia of Agricultural, Food, and Biological Engineering. Marcel Dekker Inc. 
Wan Saidatul Syida, W. K., A. Noriham, I. Normah, M. Mohd Yusuf. 2018. Changes in chemical composition and amino acid content of soy protein isolate (SPI) from tempeh. International Food Research Journal, 25(4):1528-1533.

Wijatniko, B. D. 2013. Formula Bubur MP-ASI dengan Mocaf, Beras Merah dan Tempe Koro Putih (Phaseolus lunatus L.)." Universitas Gadjah Mada. Tersedia pada: http://etd.repository.ugm.ac.id/index.php?mod=penelitian_detail\&sub=PenelitianDe tail\&act=view\&typ=html\&buku_id=62426\&is_local=1 (Diakses: 30 Agustus 2018).

World Health Organization. 2001. Complementary Feeding: Family Foods for Breastfed Children. Departement of Nutrition adn Development. Geneva.

Zamberlin, Š., N. Antunac, J. Havranek, dan D. Samaržija. 2012. Mineral Elements in Milk and Dairy Products," Mljekarstvo, 62(2):111-125. 